\title{
Visualizing nerve fibers surrounding a brachial plexus tumor using MR diffusion tensor imaging
}

Figure Tractography of a right C4 nerve schwannoma

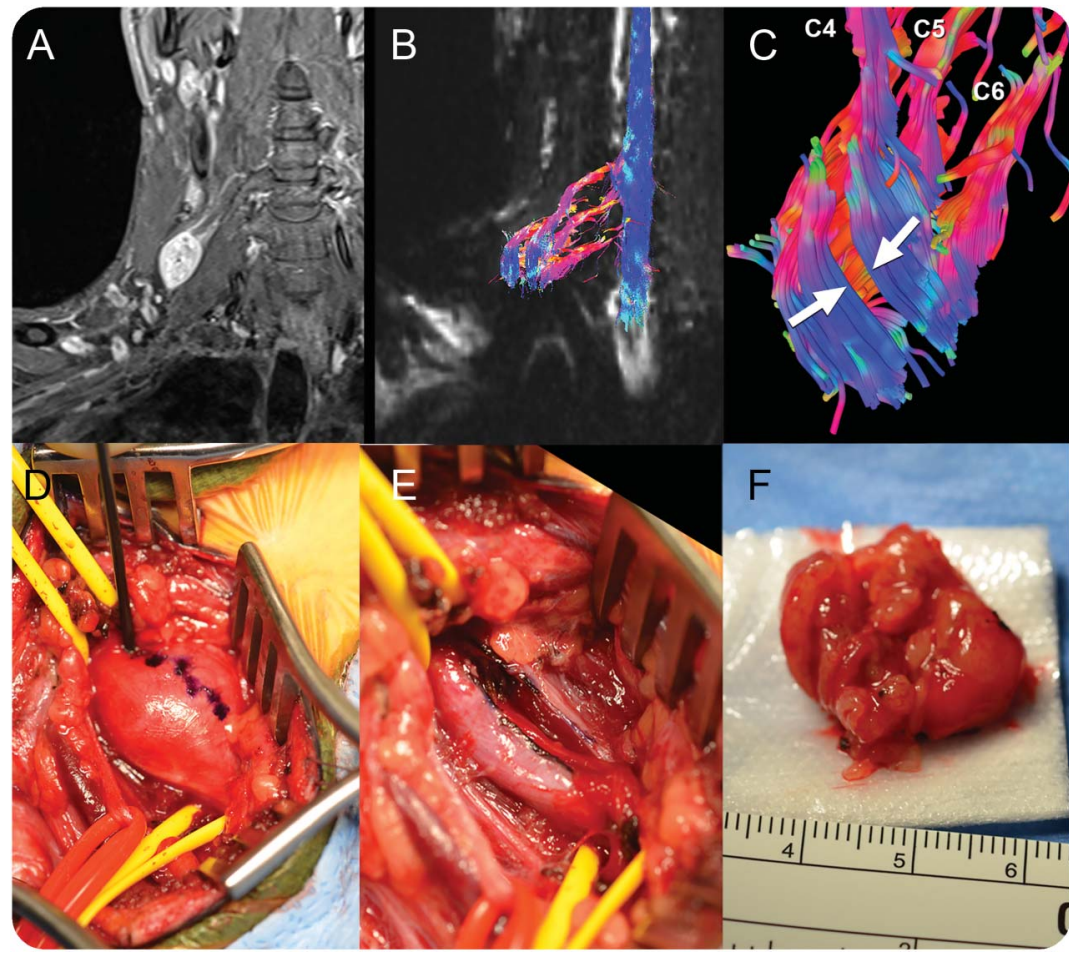

T1 postcontrast reveals an enhancing right $\mathrm{C} 4$ schwannoma (A). Tractography demonstrated nerve fibers surrounding the tumor $(B, C)$ with thinning along the anterior face (white arrows); findings confirmed on electrophysiologic mapping ( $D$; purple markings). The tumor was incised in the fiber-free zone (E) and removed in a single piece (F).

A 25-year-old man developed a growing neck mass, and percutaneous biopsy yielded diagnosis of schwannoma. The patient underwent magnetic resonance (MR) neurography, including diffusion tensor imaging performed with RESOLVE at 3 tesla (Skyra; Siemens, Malvern, PA). Postprocessing and 3-dimensional tractography were performed in DSI studio (dsi-studio.labsolver.org). ${ }^{1}$ MR neurography confirmed a mass arising from the right C4 nerve (figure, A). Tractography localized a potential window for surgical approach in the surrounding nerve fibers (figure, B and C). Intraoperative electrophysiologic mapping and microscopy findings (figure, D-F) precisely confirmed the imaging findings. Diffusion tensor imaging and tractography may be valuable in the preoperative workup of peripheral nerve tumors. ${ }^{2,3}$

\section{Thomas A. Gallagher, MD, Neil G. Simon, PhD, FRACP, Michel Kliot, MD}

From the Departments of Radiology (T.A.G.) and Neurosurgery (T.A.G., M.K.), Northwestern University Feinberg School of Medicine, Chicago, IL; Prince of Wales Clinical School (N.G.S.), University of New South Wales; and Department of Neurology (N.G.S.), St. Vincent's Hospital, Darlinghurst, Australia.

Author contributions: Dr. Gallagher: study design, data collection and analysis, drafting the manuscript, revising the manuscript. Dr. Simon: data analysis, drafting the manuscript, revising the manuscript. Dr. Kliot: study concept and design, study supervision, data analysis, revising the manuscript for important intellectual content.

Acknowledgment: The authors thank Richard Niemczura, RT, for help with MRI acquisition.

Study funding: Dr. Simon received funding from the National Health and Medical Research Council of Australia and the Motor Neurone Disease Research Institute of Australia (grant 1039520). 
Disclosure: The authors report no disclosures relevant to the manuscript. Go to Neurology.org for full disclosures.

Correspondence to Dr. Gallagher: tgallagh@nm.org

1. Yeh FC, Verstynen TD, Wang Y, Fernandez-Miranda JC, Tseng WY. Deterministic diffusion fiber tracking improved by quantitative anisotropy. PLoS One 2013;8:e80713.

2. Simon NG, Cage T, Narvid J, Noss R, Chin C, Kliot M. High-resolution ultrasonography and diffusion tensor tractography map normal nerve fascicles in relation to schwannoma tissue prior to resection. J Neurosurg 2014;120:1113-1117.

3. Cage T, Yuh TE, Hou S, et al. Magnetic resonance diffusion tensor imaging can visualize nerve fibers and their relationship to peripheral nerve tumors. Neurosurg Focus 2015;39:E16. 


\section{Neurology}

\section{Visualizing nerve fibers surrounding a brachial plexus tumor using MR diffusion tensor imaging}

Thomas A. Gallagher, Neil G. Simon and Michel Kliot

Neurology 2016;86;582-583

DOI 10.1212/WNL.0000000000002360

\section{This information is current as of February 8, 2016}

\section{Updated Information \&} Services

References

Subspecialty Collections

Permissions \& Licensing

\section{Reprints}

including high resolution figures, can be found at: http://n.neurology.org/content/86/6/582.full

This article cites 3 articles, 0 of which you can access for free at: http://n.neurology.org/content/86/6/582.full\#ref-list-1

This article, along with others on similar topics, appears in the following collection(s):

MRI

http://n.neurology.org/cgi/collection/mri

Nerve tumor

http://n.neurology.org/cgi/collection/nerve_tumor

Information about reproducing this article in parts (figures,tables) or in its entirety can be found online at:

http://www.neurology.org/about/about_the_journal\#permissions

Information about ordering reprints can be found online:

http://n.neurology.org/subscribers/advertise

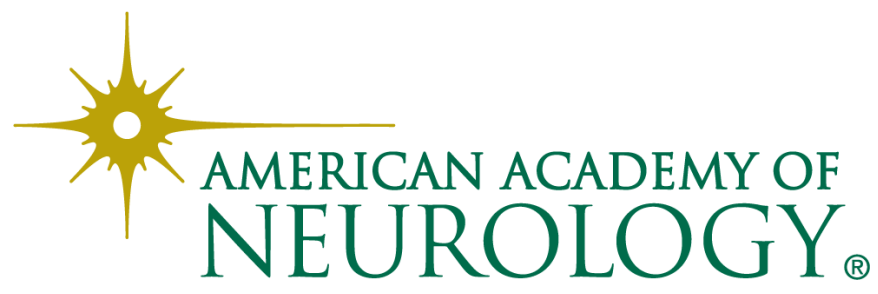

